
\title{
28 Research Square \\ Nutritional Health Status: Association of Stunted and Wasted Children and Their Mothers
}

Ulfat Khadija

University of Sargodha

Shahid Mahmood

University of Sargodha

Amara Annie

University of Sargodha

M. Yousaf Quddoos ( $\nabla$ yousafquddoos@gmail.com )

Punjab Food Authority

Hajra Ahmad

Allama Iqbal Open University

Afeefa Khadija

University of Sargodha

Syeda mahvish Zahra

University of Sargodha

Ashiq Hussain

Punjab Food Authority

\section{Research Article}

Keywords: Stunting, wasting, creatinine, genetics, dietary factors

Posted Date: July 20th, 2021

DOI: https://doi.org/10.21203/rs.3.rs-468588/v1

License: (c) (1) This work is licensed under a Creative Commons Attribution 4.0 International License.

Read Full License 


\section{Abstract}

Background: Across the globe, 149 and 49 million children are stunted and wasted, respectively. Prevalence of stunting and wasting is 40.2 and $17.7 \%$ children of Pakistan. Stunting and wasting are accompanied with genetics, dietary factor, lack of information, bottle feeding, illiterate parents, less birth interval, infection such as diarrhoea, low birth weight, mother suffering from malnutrition during pregnancy, breastfeeding, pharmaceutical, and hormonal, psychosocial, and low social-economic status.

Methods: Stunted and wasted children and their mothers were called on and detail discussions related to research plan were carried out. Informed consent was assured from mothers, for participation in the study. The demographics, anthropometrics, vital signs observations, body composition, clinical signs and symptoms, dietary intake and associated biomarkers (CBC, level of urea nitrogen in blood, serum albumin globulin and serum creatinine.) were tools for nutritional health status assessment. SPSS software was implied on data.

Results: The study found that $27.2 \%$ mothers of were belonged to stunted children, $17.3 \%$ belonged to wasted children, and $50.9 \%$ belonged to those children who were suffering from both stunting and wasting condition. $57.9 \%$ mothers who were illiterate belong to stunted and wasted children. $\mathrm{CBC}$ and $\mathrm{Hb}$ test is prominent, stunted and wasted children had Hb $9.88 \mathrm{mg} / \mathrm{dL}$, whereas, their mothers had 10.8 $\mathrm{mg} / \mathrm{dL} \mathrm{Hb}$ average. The average height and weight of stunted and wasted children was $68.6 \mathrm{~cm}$ and $7.11 \mathrm{~kg}$ respectively. Dietary patterns and diet quality of both mothers and children were poor, due to lack of affordability; they were not able to eat healthy food.

Conclusion: Stunted and wasted ultimately result in poor growth and development of children. Most of children were anemic, they height and weight less than WHO growth standards. They have less knowledge and poor intake of food diet pattern so children growth was poor

\section{Introduction}

Stunting defined as "Moderate and severe - below minus two standard deviations from median height for age of reference population" (UNICEF, 2020). Children who are small according to their age are denotes to stunting. Complements of stunted growth are irreversible physical and cognitive damage from which children might be suffering severely. Stunting can affect for late a lifetime and even it has shocking effect on next generation. (De Onis et al., 2012).

Wasting defined as "Moderate and severe - below minus two standard deviations from median weight for height of reference population" (UNICEF, 2020). Children who are too thin according to their height are denotes to be wasting. Contemporary quick weight loss or the failure to gain weight results in wasting. Moderate and severe wasted children have an increased mortality rate. However, the treatment and cure are conceivable (De Onis et al., 2012). 
As compared to girls, stunting and underweight is more common in boys. Causative factors that are associated with poor health and nutrition of children are low socioeconomic status, huge family size, lack of knowledge (Batool et al., 2012). Children are $8 \%$ and $10 \%$ stunted and wasted respectively. Considerably, wasting and stunting are not link related with gender (Mushtaq et al., 2011). Stunting is linked birth interval less than two years and with civilization (Farid-ul-Hasnain et al., 2010). Children of those fathers who are working as public employer, agriculturalists and salespersons are more stunting as associate with property-owners (Khuwaja et al., 2005).

\section{OBJECTIVES OF STUDY}

- Evaluating about dietary habits in children and their mothers

- Evaluated nutritional status of stunted and wasted children and their mother

\section{LIMITATION}

- Signs and symptoms might be taking long time to develop, due which it become difficult to link it with diet and nutritional health status

- Many signs and symptoms are not specific for stunting and wasted

- Due to lack of skinfold caliper, during research I had made use of veriner caliper

\section{Material And Methods}

\section{Research Design}

The study design was randomized controlled clinical trial (MacMahon and Trichopoulos, 1996). According to this design, firstly I had selected children of age group 6 to 60 months and their mothers, because stunting and wasting condition found in children of that age group. To found association of stunted and wasted in children and their mothers I had assessed nutritional health status of children and their mothers. Assessment consisted of four parts i.e., demographics, biomarkers, anthropometrics, and food frequency questionnaire.

\section{Nutritional Status Assessment}

\section{Permission, Approach and Informed Consent}

The written permission from mothers of Dist. Hafizabad was taken to collect data from them. The target population was approached; the research project was explained and discussed in detail. The information, education and communication (IEC) materials were provided to mothers. The informed consent was taken from the parents of the children who were part of research project (Martinez and Gonzalez, 2009).

\section{Demographics for Selection of Children}


The demographic data of the agreed parents was taken on pre-designed Performa. The children and their mothers who meet the said criteria were selected for further studies.

\section{Biomarker of Selected Children}

The blood samples of selected children were collected in coded and specified blood collecting containers for determination of $\mathrm{CBC}$, serum albumin, serum globulin, serum creatinine, and level of urea nitrogen in blood to fulfill the criteria of inclusion and exclusion as mentioned earlier.

\section{Anthropometrics and Energetic of Children}

The anthropometric measurements of the selected children like height, weight, body composition, head circumference, neck circumference, chest circumference, waist circumference, MUAC, caloric intake and caloric requirements were calculated to assess their nutritional status.

In children, body fat was measured by using Vernier Caliper, measurement of body fat was taken from sites of biceps, triceps, suprailiac, and subscapular (adapted from: Brook, 1971)

For assessment of mothers, weight, body fat, muscle mass, body water, bone mass, AMR, and BMR were calculated through BF-105 (Burer, Germany). The obtained data was compared with the standards for the evaluation of the nutritional and health status of the mothers (adapted from: Jana, 2009).

\section{Dietary Intakes Assessment}

The dietary intake history performa were filled up by me after asking from mothers of children at baseline.

\section{Clinical Assessment}

Clinical signs and symptoms related to stunting and wasting were observed in the children under study. All the information and data were used to find out the correlation between nutritional status and stunting and wasting.

\section{Medical History}

Medical history of the stunted and wasted children, and their mothers, about the prevalence of stunted and wasted was explored.

\section{Research Instruments}

a) Questionnaire: For screening/nutritional assessment of anemia

b) Biochemical tests: $\mathrm{CBC}$, level of urea nitrogen in blood, serum globulin, serum albumin, serum creatinine.

\section{Ethical Consideration}


The research proposal was approved by Biosafety and Ethical Review Committee, University of Sargodha, Sargodha (Adapted from Gibney, 2009).

\section{Delimitations and Limitations}

The target population, study locale, experts and researcher were available (delimitations) while social set up, finance, logistics, lack of availability of skinfold caliper and laboratory investigations were the constraints faced during the research work (Adapted from Delva et al., 2002).

\section{Study Population}

Children below 5 years aged were screening out for stunting and wasting and their mothers were also assessed to find relationship between stunted and wasted children and their mothers, for study by method as adapted by Muhammad, 2000.

\section{Study Location}

Primary and Secondary Healthcare Department DHQ hospital, Hafizabad was selected as study site for the research work after getting written permission from the competent authorities (adapted from: Fatahalla and Mehmoud, 2004).

\section{Sampling Technique}

The stunted and wasted children and their mothers were the target population. The selection of the children was carried out in according with two Stage Sampling that is convenience sampling technique; which a part of Non-Probability Sampling method as described by Muhammad (2000).

\section{Sample Size}

The sample size for stunted and wasted children and their mothers were calculated by the following formula; considering estimated prevalence of variable of interest (stunted and wasted), required level of confidence (95\%) and $5 \%$ margin of error (adapted by Magnani, 1997).

\section{Step 1. Base Sample Size Calculation (n)}

$$
\mathbf{n}=\frac{\mathbf{t}^{2} \times \mathbf{p}(\mathbf{1}-\mathbf{p})^{-}}{\mathbf{m}^{2}}
$$

Where,

$\mathrm{n}=$ required sample size

$\mathrm{t}=$ confidence level at $95 \%$ (standard value of 1.96 )

$p=$ estimated/reported prevalence of stunted and wasted children among children of age group 6 to 60 months in Pakistan

$m=$ margin of error at $5 \%$ (standard value of 0.05 ) 


\section{Step 2: Design Effect (D)}

To minimize the design effect; the sample size was multiplied by 2 that is considered as $D$ for nutritional studies.

\section{Step 3: Contingency (Final Sample Size)}

Final sample size was calculated by given formula.

$n_{\text {final }}=(n \times D)+5 \%$ of $(n \times D)$

Where,

$\mathrm{n}_{\text {final }}=$ final sample size

$\mathrm{n} \times \mathrm{D}=$ sample size with design effect

$5 \%=$ the calculation and addition of $5 \%$ accounted for contingencies which were represent no response, drop out and data recording errors

So, the sample size of my study was 57 for stunted children and 25 for wasted children.

\subsubsection{Data Collection and Analysis}

Data was presented with the help of tables, charts, and graphs where necessary. Data collected was analyzed with the help of statistical software (SPSS). Appropriate statistical tests were used. Both parametric and non-parametric tests were used for testing significance. Descriptive statistics were run to check the distribution and frequency of data. Analysis of variance and post hock LSD was applied to seek the level of significance.

\section{Results And Discussion}

The basic purpose of study is find association of stunted and wasted children and their mothers for their nutritional health status. There is large number of stunted and wasted children age of 6 months to 5 years age. Those children who were part of study having religion Islam, Pakistani nationality, and their mothers were housewife. The basic factors of stunted and wasted children are poor diet. In study children whose age is between 6 months to 5 years and their mothers were included in nutritional assessment. Nutritional health status assessment includes demographics of mothers, biomarkers of children, biomarkers of mothers, anthropometric measurement of stunted and wasted children and their mothers, FFQ of mothers and FFQ of children were divided in two groups according to their age group i.e., in 1 st group FFQ of children from 6 to 24 months were included, whereas in 2nd group children whose age is from 2 to 5 years were included. The observed results mentioned below.

\section{Demographics of Mothers}


Table 1 showed that all mothers who come with children in hospital were Pakistani. The prevalence of stunted, wasted, and stunted and wasted children was $27.17 \%, 17.34 \%$ and $50.87 \%$, respectively. Majority of mothers having stunted and wasted children which are about $60.0 \%$ belonged to age group of is 30-45 years while $47.07 \%$ mothers having stunted and wasted children belonged to age group of 18-30 years. It is evident that children of those mothers of age group 30-45, were more prone to be stunted and wasted. In a study it was observed that if age of mother is more than 18 years and visit parental care clinic more than 3 times during pregnancy, children of those mothers were likely to less stunted (Khan et al., 2019). In some studies it was observed that most of mothers with stunted and wasted children mean average rang of age were $30.3 \pm 6.0$ years about $75.3 \%$ with stunted and wasted children (Ali et al., 2017). Children whose mothers lived in rural areas were more likely to have stunted and wasted children i.e. $57.6 \%$, whereas those mothers who lived in urban areas $44.1 \%$ belonged to stunted and wasted children. Majority of mothers of those children who were likely to be more stunted and wasted lived in rural areas i.e. 56.7\% (Khan et al., 2019). In a dissimilar study, it was observed in Indonesia that children who lived in rural areas were less prone to be stunted as compared to those children who lived in urban area (Yalew et al., 2014). In a similar study, prevalence of stunting and wasting higher in rural areas as compared to urban areas (Arif et al., 2012). Mothers who lived nuclear family system, i.e. $60.5 \%$ belonged to stunted and wasted children on the other hand $41.4 \%$ mothers who come to hospital were lived in joined family system, belonged to stunted and wasted children. In a similar study, it was observed that the children of nuclear family more likely to be stunted and wasted (Khan et al., 2015). In another similar study, which was conducted in Pakistan, results showed that stunting and wasting mostly prevalent among children of nuclear family system as compared to joint family system (Mahmood et al., 2016). It was revealed that mothers who had sedentary physical activity were belonged to $50 \%$ stunted and wasted children, whereas those mothers who had light active physical activity belonged to $51.2 \%$ stunted and wasted children. In a study, it was indicated mothers who did not work had less significant proportions of stunting i.e. $43.4 \%$ in contrast to mothers who work for the same period that was $49.8 \%$, whereas proportion of wasting was significant in those mothers who did not work in contrast to those mothers who worked (Kimani-Murage et al., 2015).

\section{Biomarkers of children}

From Table 2, it was revealed that results were highly significant, the level of all components of blood were decreased in stunted and wasted children. $\mathrm{Hb}$ is most important component of blood, its decrease level show that children were anemic. $\mathrm{Hb}$ of normal children was $12.59(\mathrm{mg} / \mathrm{dL})$, stunted children $\mathrm{Hb}$ was $11.8(\mathrm{mg} / \mathrm{dL})$, wasted children $\mathrm{Hb}$ was $10.85(\mathrm{mg} / \mathrm{dL})$, and whereas those children who were both stunted and wasted have $\mathrm{Hb} 9.88(\mathrm{mg} / \mathrm{dL})$. In a similar study, level of $\mathrm{Hb}$ decreased in stunted and wasted children, anemia was observed in them (Ehrhardt et al., 2006). Low level of Hb was observed in stunted children, prevalence of anemia is higher among stunted children (Rahman et al., 2019). In other similar study, it was observed that stunted and wasted children anemic (Thakur et al., 2014).

\section{Anthropometrics of children}


In Table 3, non-significant results were found. It was found that normal children have 63.6 average value of pulse rate, stunted have 62.63 pulse rates, wasted have 60.77 pulse rate, and whereas both stunted and wasted have 57.31 pulse rates. In a similar study, it was observed that stunting and wasting children were at risk of developing congenital heart disease and is associated with anemia and heart failure due to pulse rate of children decreased (Batte et al., 2017). Non-significant result was concluded, from it was found children who were normal have $98.58^{\circ} \mathrm{F}$ temperature, stunted children have $98.38^{\circ} \mathrm{F}$, wasted children have $98.28^{\circ} \mathrm{F}$, and those children who were both stunted and wasted have $97.87^{\circ} \mathrm{F}$. Nonsignificant results were observed related to blood oxygen saturation. It was observed that children who were normal have 98.25 , stunted have 97.32 , wasted have 95.34, and both stunted and wasted children have 94.76 blood oxygen saturation levels. In Table 6, significant results were concluded. So, it was observed that those children who were normal have average height $76.03 \mathrm{~cm}$, stunted children have average height $72.75 \mathrm{~cm}$, wasted children have average height $72.5 \mathrm{~cm}$, whereas those children who were both stunted and wasted have average height $68.6 \mathrm{~cm}$. In a study, it was concluded that children who were stunted and wasted, were at greater risk of linear growth retardation particularly in children aged 12-23 months (Saaka and Galaa, 2016). Highly significant results were obtained related to weight of children. Children who were normal have $9.41 \mathrm{~kg}$ was average weight, stunted children have $9.13 \mathrm{~kg}$ was average weight, wasted children have $7.23 \mathrm{~kg}$ average weight, and some children who were both stunted and wasted have $7.11 \mathrm{~kg}$ average weight. In a study, it was observed that the wasted children were interpreted as those children who have low value of weight for height in that condition muscle and body fat were reduced, that is, the child is wasted (Golden 1995). Highly significant value of triceps was obtained. Average value of triceps in normal children $8.22 \mathrm{~mm}$, in stunted children $8.04 \mathrm{~mm}$, in wasted children $6.32 \mathrm{~mm}$, in those children who were both stunted and wasted low value of triceps $6.05 \mathrm{mmwas}$ observed. In one study, significant results related to triceps were found, $8.57 \mathrm{~mm}$ in girls and $8.15 \mathrm{~mm}$ in boys triceps (Garenne et al., 2019). Non-significant value of biceps was revealed. Average value of biceps was found in normal children have $6.65 \mathrm{~mm}$, in stunted children have $6.56 \mathrm{~mm}$, in children have wasted $6.25 \mathrm{~mm}$, and least average value of biceps observed in both stunted and wasted have $5.65 \mathrm{~mm}$. Highly significant result related to subscapular was observed. Normal children have $8.39 \mathrm{~mm}$, stunted children have $8.3 \mathrm{~mm}$, wasted children have $6.22 \mathrm{~mm}$, and whereas those children who were both stunted and wasted have $6.13 \mathrm{~mm}$ average value of subscapular. In a similar study highly significant result were found, girls had $6.31 \mathrm{~mm}$ and boys had $5.98 \mathrm{~mm}$ of subscapular (Garenne et al., 2019). Non-significant results were obtained related to suprailiac. Average value of suprailiac in different group of children such as normal children have $9.09 \mathrm{~mm}$, stunted children have $7.19 \mathrm{~mm}$, wasted children have $6.58 \mathrm{~mm}$, and those children who were both stunted and wasted have $5.79 \mathrm{~mm}$.

From Table 4, highly significant results were found about waist circumference of children. Average value of waist circumference that observed in normal children group has $43.18 \mathrm{~cm}$, group of stunted children have $42.25 \mathrm{~cm}$, group of wasted children have $39.5 \mathrm{~cm}$, and group of those children who were both stunted and wasted have $39.26 \mathrm{~cm}$. In a study, dissimilar results were found, in most of children waist circumference of children was normal (Meko et al., 2015). Average value of MUAC that had been observed in group of normal children had $13.91 \mathrm{~cm}$, stunted children had $13.74 \mathrm{~cm}$, wasted children had 
$11.69 \mathrm{~cm}$, and group of those children who were both stunted and wasted had $11.45 \mathrm{~cm}$. in a similar study similar result were found, MUAC of children was low, who were stunted wasted and underweight (Odei Obeng Amoako et al., 2020). In a study similar most significant results were found, children who were wasted had MUAC less than $11.5 \mathrm{~cm}$ (Berkley et al., 2005). It was observed that normal children have $44.5 \mathrm{~cm}$, stunted children have $44.27 \mathrm{~cm}$, wasted children have $42.87 \mathrm{~cm}$, and a group of those children who were both stunted and wasted have $42.14 \mathrm{~cm}$ average value of head circumference. In a similar study, significant results of head circumference were obtained (Garenne et al., 2019). In a similar study, significant results related head circumference were obtain that stunted children had $44.67 \mathrm{~cm}$ and waste children had $48.54 \mathrm{~cm}$ head circumference (Post and Victora, 2001). Group of normal children have $43.63 \mathrm{~cm}$ chest circumference, group of stunted children had average value of chest circumference $41.57 \mathrm{~cm}$, group of wasted children have average value of chest circumference that was $39.84 \mathrm{~cm}$, and in group of those children who were both stunted and wasted had $39.16 \mathrm{~cm}$ average value of chest circumference. In a study, non-significant result were revealed, stunted children had $49.17 \mathrm{~cm}$ and wasted children and $49.79 \mathrm{~cm}$ chest circumference (Post and Victora, 2001). Neck circumference of children who were normal had $24.73 \mathrm{~cm}$, stunted had $23.86 \mathrm{~cm}$, wasted had $23.17 \mathrm{~cm}$, and group of both stunted and wasted had $21.4 \mathrm{~cm}$ average value.

\section{Anthropometric of mothers}

In Table 5, non-significant result was revealed. Mothers of normal children average pulse rate were 96.13, those of stunted children's mother have 92.87 average pulse rate, mothers of wasted children average pulse rate were 90.26 , and whereas it was observed that mothers of stunted and wasted average pulse rate was 88.68. Observations were made that non-significant results were revealed related to body temperature of mothers. Mothers of normal children have $98.4^{\circ} \mathrm{F}$, mothers of stunted children have $98.3^{\circ} \mathrm{F}$, and mothers of wasted children have $98.19^{\circ} \mathrm{F}$, and while, mothers of stunted and wasted children have $98.06^{\circ} \mathrm{F}$ average body temperature. Non-significant results were observed related to blood oxygen saturation, Blood oxygen saturation of mothers, who have normal children was 97.79 , mother of stunted children has 97.53 , mothers of wasted have 97.4 , and mothers of both stunted and wasted have 97.13 . In Table 8, non-significant results about height were observed, mothers had average height of normal children had $152.17 \mathrm{~cm}$, while, mothers of stunted children had $151.27 \mathrm{~cm}$, whereas mothers of wasted had $151.15 \mathrm{~cm}$ and mothers of both stunted and wasted $150.25 \mathrm{~cm}$ respectively. In a dissimilar study, significant result related to height of mothers, it was observed in that study that mothers whose were short statures $<145 \mathrm{~cm}$ height were more likely to had stunted children (Khan et al., 2019). In another study, it was revealed that those mothers have height less than $150.1 \mathrm{~cm}$ were more like to have stunted children (Addo et al., 2013). In one study, it was observed that height of mothers showed negative relation with stunted but not wasted children (Ali et al., 2017). Non-significant results were obtained about weight of mothers, mothers had average weight of normal children had $64.55 \mathrm{~kg}$, while, mothers of stunted children had $61.67 \mathrm{~kg}$, whereas mothers of wasted had $60.46 \mathrm{~kg}$, and mothers of both stunted and wasted $57.72 \mathrm{~kg}$ respectively. Body fat of mothers was showed non-significant results, mothers' body composition was assessed, through assessment body fat, was observed, from which mothers of normal children had $34.39 \%$, mothers of stunted children, $34.74 \%$, mothers of wasted children had $35.75 \%$, and, 
mothers of both stunted and wasted had $37.38 \%$. Non-significant result about body water in mothers was found, mothers of normal children had $44.66 \%$ body water, stunted children mothers had $43.74 \%$ body water, mothers of wasted children had $43.65 \%$ body water, and mothers of both stunted and wasted had $42.54 \%$ body water. Non-significant results were revealed about the muscle mass of mothers. Muscle mass was measured of mothers by BF105 machine, mothers of normal children had $31.58 \%$, mothers of stunted children had $31.17 \%$, mothers of wasted children had $30.89 \%$, and mothers of both stunted and wasted children had $31.49 \%$. Non-significant results were found about bone mass of mothers. In Table 8, mothers of normal children have $9.44 \%$ bone mass, mothers of stunted children have $9.33 \%$ bone mass, mothers of wasted children have $9.33 \%$ bone mass, and mothers of stunted and wasted children have $9.19 \%$ bone mass.

In Table 6, non-significant results were obtained, mothers of healthy children AMR were assessed, whereas mothers of normal children had 1676.75, mothers of stunted children had 1650.94, mothers of wasted had 1627.01 mothers of both stunted and wasted had 1579.93. Mothers BMR was assessed, whereas mothers of normal children had 1368.23, mothers of stunted children had 1317.75, mothers of wasted had 1267.62 and mothers of both stunted and wasted had 1238.23. Head circumference of mothers were revealed, mothers of normal children had $52.07 \mathrm{~cm}$ head circumference, stunted children's mothers had $52.92 \mathrm{~cm}$, those of wasted children's mothers had $52.92 \mathrm{~cm}$, and while mother of both stunted and wasted had $52.5 \mathrm{~cm}$. In Table 6, non-significant results were disclosed about waist circumference of mothers, mothers of normal children had $95.63 \mathrm{~cm}$ waist circumference, mothers of stunted children had $92.55 \mathrm{~cm}$ waist circumference, mothers of wasted children had $91.87 \mathrm{~cm}$ waist circumference, and mothers of both stunted and wasted mothers had $91.63 \mathrm{~cm}$ waist circumference. In a study dissimilar result was revealed that mothers' waist circumference show positive relationship with their children who were stunted (Egal and Oldewage, 2014). Non-significant result was divulging related to MUAC, mothers of healthy children had $27.35 \mathrm{~cm}$ MUAC, mothers of stunted children had $26.08 \mathrm{~cm}$ MUAC, mothers of wasted children had $25.88 \mathrm{~cm}$ MUAC, and mothers of both stunted and wasted had $25.36 \mathrm{~cm}$ MUAC. In a study, MUAC of mothers who were belonged to stunted and wasted children had less than $23.5 \mathrm{~cm}$ (Post and Victora, 2001). It was founded that mothers of normal children had 89.88 $\mathrm{cm}$, stunted children's mothers had $87.65 \mathrm{~cm}$, mothers of wasted children had $86.65 \mathrm{~cm}$, and on the other hand, mothers of both stunted and wasted mothers had $86.4 \mathrm{~cm}$. Neck circumference of mothers was measured, mothers of normal children had $32.89 \mathrm{~cm}$, stunted children's mothers had $32.68 \mathrm{~cm}$, wasted children's mothers had $32.16 \mathrm{~cm}$, and mothers of both stunted and mothers had $31.55 \mathrm{~cm}$.

\section{Food frequency questionnaire of children}

To find better result related to food intake of children, they were divided into two groups according to their age i.e. 6-24 months and 24 to 60 months. The intake of children whose age below than 24 months as compared to those whose age is more than 24 months. From Table 7: it concluded that intake of all food groups were less in children of age group (6-2 months), they take 2.1 serving per week of cereals, 2.74 servings per week of fruit, 0.47 servings per week of vegetables, 0.66 servings per week of meat group, 68.86 servings per week of milk, 0.34 servings per week of fat \& oil, 4.78 servings per week of junk/snack, 
0.86 servings per week of miscellaneous, and 0.73 litter per week of water. On the other hand, children belong to age group (24-60 months), were taking more food groups servings per week. They take average 10.41 servings per week of cereals, 7.87 servings per week of fruits, 1.18 servings per week of vegetables, meat 2.87, 53.61 servings per week of milk, fat \& oil 3.13 servings per week, junk/snack 8.6 servings per week, miscellaneous 6.73 servings per week, and 1.75 liters per week of water. In one study, it was found about food that consumption of starchy staples, legumes, and oil was common. Whereas, intake of fruits and vegetables were less in children. About half children were consumed dairy products. Intake of egg and fish was also limited (Dorsey et al., 2018). In other study, they also divided the children in two group i.e. 6-24 and 24-60 months, it was revealed that intake of children, that they daily consumed less amount of vegetables and meat but high intake of soft drink, fried food salty snack, and sweets (Bortolini et al., 2012).

\section{Food frequency questionnaire of mothers}

In Table 8, non-significant results were obtained related to intake of cereals, it was concluded that 63.13 servings per week of cereals were taken by mothers of children who were stunted and wasted, they were take less serving of cereals as compared to mothers of healthy children i.e. 72.5 servings per week. It was observed that all mothers were taking more 6 servings per day of cereals either they belong to mothers of stunted and wasted children or mothers of healthy children. Non-significant results were observed related to intake of fruits servings, it was concluded that least 9.5 servings per week of fruits were taken by those mothers of children who were both stunted and wasted, they were taking less servings as compared to recommended servings of fruits, for healthy persons it is recommended that they should take 2-4 servings of fruits on daily basis. While mothers of healthy children were taking 16.81 servings per week of fruits, they are taking more than 2 servings of fruits. So it was concluded that mothers of stunted and wasted taking less fruits due to lack of affordability of fruit due to which nutritional status of children was also affected. It was disclosed that less 15.25 servings per week of vegetables were taken by mothers of stunted and wasted children. They were taking less than 3-5 servings per day of vegetables that recommended according to food pyramid, whereas mothers of healthy children were taking 24.67 servings per week of vegetables, they were taking more than 3 servings per day of vegetables, so it showed that less intake of vegetables by mothers had its effect on the health of children. It was observed that mothers of stunted and wasted children had least intake of meat i.e., 5.73 servings per week as compare to mothers of healthy children i.e. 7.5 servings per week. From study it was concluded that mothers of all children were taking less than recommended servings of meat group i.e. 2-3 servings per day. Results related to intake of milk showed variations, it can be concluded that mothers of stunted and wasted children have least 7.88 servings of milk per week as to compare to mothers of healthy children i.e. 12.77. It was revealed that mothers of stunted and wasted children were taking less 2 servings of milk per day which also affected the nutritional status of children. It was observed that mothers of stunted and wasted children had high 18.17 servings per week of fat and oil intake as compared to mothers of healthy children, whose intake was 12.75 servings per week. Sparingly used of fat and oil is recommended but their intake of fat and oil was increased. This also affected the nutritional status of children. It was concluded that highest 26.98 servings per week of junk and snack were observed in

Page $11 / 25$ 
mothers of stunted and wasted children but zero serving of junk and snack was recommended. So this showed that all mothers had intake of junk and snack food group, this showed negative impact on the health of children. Non-significant results were concluded related to miscellaneous food intake, it was observed that highest 1.75 servings per week of miscellaneous food were taken by mothers of stunted and wasted children. Fewer servings were taken by mothers of healthy children. Non-significant results were concluded related to water intake, mothers of children who were stunted and wasted taken $7.19 \mathrm{~L}$ per week; they had least intake of water than mothers of healthy children.

\section{Conclusion}

From the result of present study, it was revealed that $27.17 \%$ children were stunted, $17.34 \%$ children were wasted, and $50.87 \%$ children were stunted and wasted. Stunted and wasted at this stage ultimately result in poor growth and development of children. Most of children were anemic, they height and weight less than WHO growth standards. Intake of food was observed in children and mothers they had poor diet pattern. Due to poor food habits growth of children were poor. Due to lack of maternal education, low socio-economic status, poor diet, and lack of awareness about healthy and balanced diet. Government should take serious steps concerning with stunting and wasting health issues for the prosperous and healthy nation.

\section{Abbreviations}

FFQ (food frequency questionnaire), AMR (active metabolic rate), BMR (Basel metabolic rate)

\section{Declarations}

\section{Ethics approval and consent to participate:}

No ethical approval document is required for the research because this research is conducted as serve. Consent of participant was taken.

\section{Consent for publication:}

was taken from parents that their collectively data will be publish

\section{Availability of data and materials:}

collective data after state is available for publish but data cannot be provided by individual author

\section{Competing interests:}

no any author has conflict of interest

\section{Funding:}


No funding was taken and still no funding available for publication of data

\section{Authors Contribution:}

Ulfat Khadija and Afeefa performed the health assessment of volunteers and fill the forms.

Dr. Shahid Mahmood and Amara annie gave the guide line about how to perform the health assessment activity and paper write-up.

Dr. Muhammad Yousaf Quddoos received the data from researcher and arranged the data in paper shape for uploading to journal

Hajra Ahmad proofed reading of data

Syeda mahvish Zahra and Ashiq Hussain applied the sate on data, arranged the tables and remove the plagiarism

\section{Acknowledgements:}

Authors are thankful to the management of District Head Quarter of hafizabad \& University of Sargodha for organizing this research.

\section{References}

1. Addo OY, Stein AD, Fall CH, Gigante DP, Guntupalli AM, Horta BL, Kuzawa CW, Lee N, Norris SA, Prabhakaran P, Richter LM. Maternal height and child growth patterns. The Journal of pediatrics. 2013 Aug 1;163(2):549-54.

2. Ali Z, Saaka M, Adams AG, Kamwininaang SK, Abizari AR. The effect of maternal and child factors on stunting, wasting and underweight among preschool children in Northern Ghana. BMC nutrition. 2017 Dec;3(1):1-3.

3. Arif GM, Nazir S, Satti MN, Farooq S. Child malnutrition in Pakistan: Trends and determinants. Pak Inst Dev Econ. 2012 Jul;2012:1-8.

4. Batool SA, Shaheen AN, Rehman RA, Qamar S, Ahsan Raza SM, Jabeen R, Nisa F. To assess the nutritional status of primary school children in an Urban school of Faisalabad. Pak. J. Med. Health Sci. A. 2012;4:160.

5. Batte A, Lwabi P, Lubega S, Kiguli S, Otwombe K, Chimoyi L, Nabatte V, Karamagi C. Wasting, underweight and stunting among children with congenital heart disease presenting at Mulago hospital, Uganda. BMC pediatrics. 2017 Dec;17(1):1-7.

6. Berkley J, Mwangi I, Griffiths K, Ahmed I, Mithwani S, English M, Newton C, Maitland K. Assessment of severe malnutrition among hospitalized children in rural Kenya: comparison of weight for height and mid upper arm circumference. Jama. 2005 Aug 3;294(5):591-7. 
7. Bortolini GA, Gubert MB, Santos LM. Food consumption among Brazilian children aged 6 to 59 months. Public Health Notebooks. 2012; 28: 1759-71.

8. Brook CG. Determination of body composition of children from skinfold measurements. Archives of disease in childhood. 1971 Apr 1;46(246):182-4.

9. De Onis M, Blössner M, Borghi E. Prevalence and trends of stunting among pre-school children, 1990-2020. Public health nutrition. 2012 Jan;15(1):142-8.

10. Delva MD, Kirby JR, Knapper CK, Birtwhistle RV. Postal survey of approaches to learning among Ontario physicians: implications for continuing medical education. Bmj. $2002 \mathrm{Nov}$ 23;325(7374):1218.

11. Dorsey JL, Manohar S, Neupane S, Shrestha B, Klemm RD, West Jr KP. Individual, household, and community level risk factors of stunting in children younger than 5 years: Findings from a national surveillance system in Nepal. Maternal \& child nutrition. 2018 Jan;14(1):e12434.

12. Egal AA, Oldewage-Theron WH. Maternal waist circumference as a prediction of children's stunted status. South African Journal of Clinical Nutrition. 2014 Oct 10;27(3):108-9.

13. Ehrhardt S, Burchard GD, Mantel C, Cramer JP, Kaiser S, Kubo M, Otchwemah RN, Bienzle U, Mockenhaupt FP. Malaria, anemia, and malnutrition in African children-defining intervention priorities. The Journal of infectious diseases. 2006 Jul 1;194(1):108-14.

14. Farid-ul-Hasnain S, Sophie R. Prevalence and risk factors for Stunting among children under 5 years: a community based study from Jhangara town, Dadu Sindh. J Pak Med Assoc. 2010 Jan 1;60(1):41-.

15. Fatahalla, MF., \& Mahmoud, FF.. A practical guide for health researchers. WHO Regional Publications Eastern Mediterranean Series, (2004) (30), 234.

16. Garenne M, Myatt M, Khara T, Dolan C, Briend A. Concurrent wasting and stunting among under-five children in Niakhar, Senegal. Maternal \& child nutrition. 2019 Apr;15(2):e12736.

17. Gibney, MJ., Lanham-New, SA., Cassidy, A., \& Vorster, HH. Introduction to Human Nutrition. John Wiley and Sons. (2013).

18. Golden MH. Specific deficiencies versus growth failure: type I and type II nutrients. SCN news. 1995(12):10-4.

19. Khan S, Zaheer S, Safdar NF. Determinants of stunting, underweight and wasting among children< 5 years of age: evidence from 2012-2013 Pakistan demographic and health survey. BMC public health. 2019 Dec 1;19(1):358.

20. Khan T, Khan RE, Raza MA. Gender analysis of malnutrition: a case study of school-going children in Bahawalpur. Asian Development Policy Review. 2015;3(2):29-48.

21. Khuwaja S, Selwyn BJ, Shah SM. Prevalence and correlates of stunting among primary school children in rural areas of southern Pakistan. Journal of tropical pediatrics. 2005 Apr 1;51(2):72-7.

22. Kimani-Murage EW, Muthuri SK, Oti SO, Mutua MK, Van De Vijver S, Kyobutungi C. Evidence of a double burden of malnutrition in urban poor settings in Nairobi, Kenya. PloS one. 2015 Jun 
22;10(6):e0129943.

23. Magnani R. Sampling guide: food and nutrition technical assistance project (FANTA). Academy for Educational Development, Washington, DC. 1997;46.

24. Meko LN, Walsh CM, Kruger SH, Slabber-Stretch M, Nel M,. School environment, socioeconomic status and weight of children in Bloemfontein, South Africa. African Journal of Primary Health Care and Family Medicine. 2015 Jan 1;7(1):1-7.

25. Muhammad, F.. Non-probability sampling methods. Statistical methods and data analysis. Kitab Markaz Faisalabad, (2000). 468-469.

26. Mushtaq MU, Gull S, Khurshid U, Shahid U, Shad MA, Siddiqui AM. Prevalence and sociodemographic correlates of stunting and thinness among Pakistani primary school children. BMC public health. 2011 Dec;11(1):1-2.

27. Odei Obeng-Amoako GA, Myatt M, Conkle J, Muwaga BK, Aryeetey R, Okwi AL, Okullo I, Mupere E, Wamani $\mathrm{H}$, Briend A, Karamagi CA. Concurrently wasted and stunted children 6-59 months in Karamoja, Uganda: prevalence and case detection. Maternal \& child nutrition. 2020 Oct;16(4):e13000.

28. Post CL, Victora CG. The low prevalence of weight-for-height deficits in Brazilian children is related to body proportions. The Journal of nutrition. 2001 Apr 1;131(4):1290-6.

29. Rahman MS, Mushfiquee M, Masud MS, Howlader T. Association between malnutrition and anemia in under-five children and women of reproductive age: Evidence from Bangladesh Demographic and Health Survey 2011. PloS one. 2019 Jul 3;14(7):e0219170.

30. Saaka M, Galaa SZ. Relationships between wasting and stunting and their concurrent occurrence in Ghanaian preschool children. Journal of nutrition and metabolism. 2016 Jan 1;2016..

31. Thakur N, Chandra J, Pemde H, Singh V. Anemia in severe acute malnutrition. Nutrition. 2014 Apr 1;30(4):440-2.

32. UNICEF, (2020). Nutrition. [available at:https://www.unicef.org/infobycountry/stats_popup2.html; assessed on: March 3, 2020].

33. Yalew BM, Amsalu F, Bikes D. Prevalence and factors associated with stunting, underweight and wasting: a community based cross sectional study among children age 6-59 months at Lalibela Town, Northern Ethiopia. J Nutr Disorders Ther. 2014;4(147):2161-0509.

\section{Tables}


Table 1

Demographics of mothers

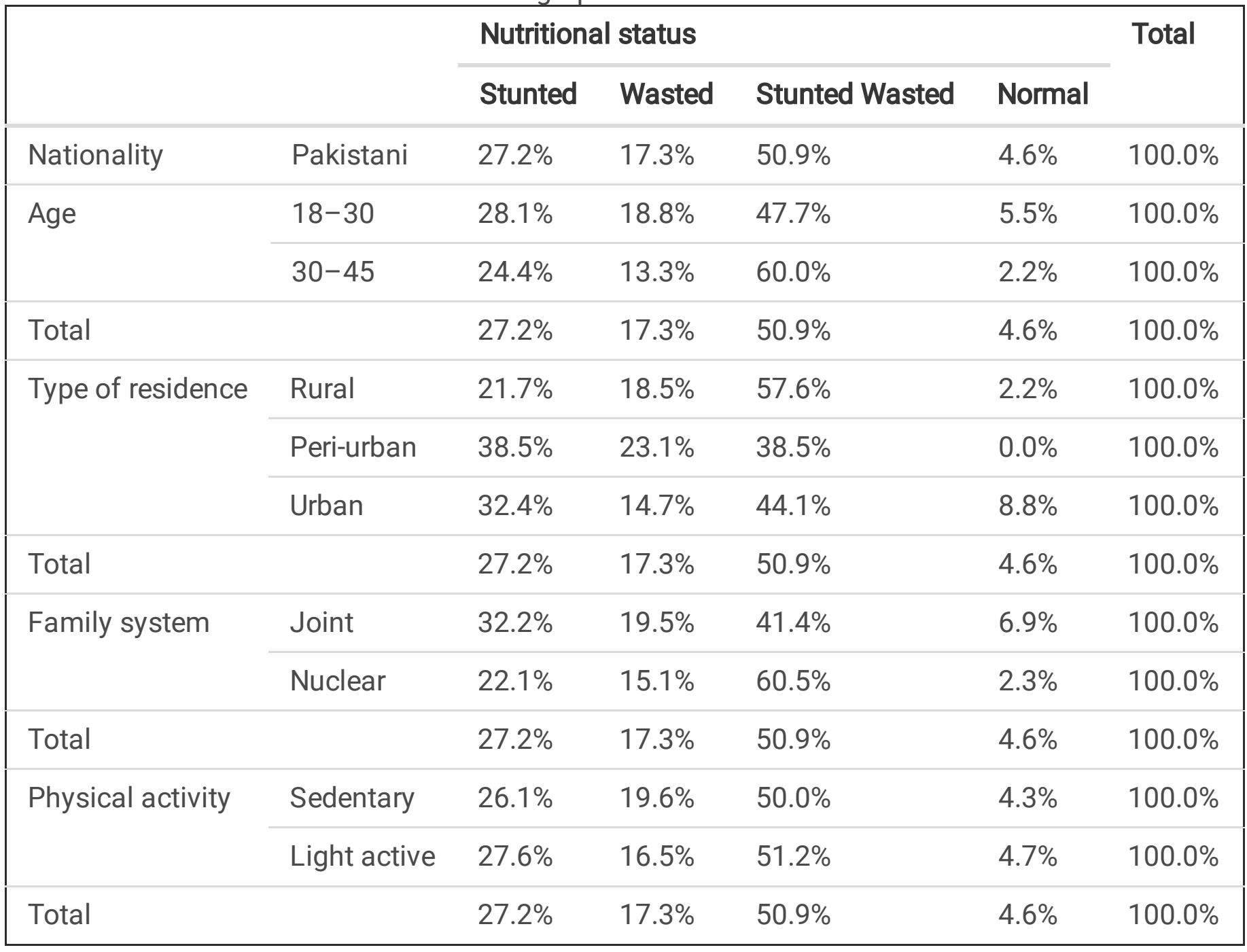

Table 2

Biomarkers of Children

\begin{tabular}{|llll|}
\hline Biomarkers & Groups & Value & P values \\
\hline Hemoglobin & Normal & $12.59 \pm 0.18 \mathrm{~A}$ & \multirow{2}{*}{0 ** } \\
\cline { 2 - 3 } & Stunted & $11.8 \pm 0.21 \mathrm{~B}$ & \\
\cline { 2 - 3 } & Wasted & $10.85 \pm 0.53 \mathrm{C}$ & \\
\cline { 2 - 3 } & Stunted and Wasted & $9.88 \pm 0.21 \mathrm{D}$ & \\
\hline
\end{tabular}


Table 3

Anthropometric of children

\begin{tabular}{|c|c|c|c|}
\hline & Groups & Value & $P$ values \\
\hline \multirow[t]{4}{*}{ Pulse Rate } & Normal & $63.6 \pm 2.61 \mathrm{~A}$ & \multirow[t]{4}{*}{$0.708^{N S}$} \\
\hline & Stunted & $62.63 \pm 11.8 \mathrm{~A}$ & \\
\hline & Wasted & $60.77 \pm 4.02 \mathrm{~A}$ & \\
\hline & Stunted and Wasted & $57.31 \pm 4.54 \mathrm{~A}$ & \\
\hline \multirow[t]{4}{*}{ Temperature } & Normal & $98.58 \pm 0.13 \mathrm{~A}$ & \multirow[t]{4}{*}{$0.195^{\mathrm{NS}}$} \\
\hline & Stunted & $98.38 \pm 0.32 \mathrm{AB}$ & \\
\hline & Wasted & $98.28 \pm 0.19 A B$ & \\
\hline & Stunted and Wasted & $97.87 \pm 0.42 B$ & \\
\hline \multirow[t]{4}{*}{ Blood Oxygen Saturation } & Normal & $98.25 \pm 4.02 \mathrm{~A}$ & \multirow[t]{4}{*}{$0.65^{N S}$} \\
\hline & Stunted & $97.32 \pm 1.99 \mathrm{~A}$ & \\
\hline & Wasted & $95.34 \pm 2.06 \mathrm{~A}$ & \\
\hline & Stunted and Wasted & $94.76 \pm 1.32 \mathrm{~A}$ & \\
\hline \multirow[t]{4}{*}{ Height (cm) } & Normal & $76.03 \pm 1.41 \mathrm{~A}$ & \multirow[t]{4}{*}{$0.001^{*}$} \\
\hline & Stunted & $72.75 \pm 2.26 \mathrm{AB}$ & \\
\hline & Wasted & $72.5 \pm 2.39 \mathrm{AB}$ & \\
\hline & Stunted and Wasted & $68.6 \pm 0.98 \mathrm{~B}$ & \\
\hline \multirow[t]{4}{*}{ Weight (kg) } & Normal & $9.41 \pm 0.37 \mathrm{~A}$ & \multirow[t]{4}{*}{$0 * \star$} \\
\hline & Stunted & $9.13 \pm 0.6 \mathrm{~A}$ & \\
\hline & Wasted & $7.23 \pm 0.38 \mathrm{~B}$ & \\
\hline & Stunted and Wasted & $7.11 \pm 0.22 \mathrm{~B}$ & \\
\hline \multirow[t]{4}{*}{ Triceps (mm) } & Normal & $8.22 \pm 0.2 \mathrm{~A}$ & \multirow[t]{4}{*}{$0 \star \star$} \\
\hline & Stunted & $8.04 \pm 0.58 \mathrm{~A}$ & \\
\hline & Wasted & $6.32 \pm 0.36 \mathrm{~B}$ & \\
\hline & Stunted and Wasted & $6.05 \pm 0.22 B$ & \\
\hline \multirow[t]{2}{*}{ Biceps (mm) } & Normal & $6.65 \pm 0.26 \mathrm{~A}$ & \multirow[t]{2}{*}{$0.884^{N S}$} \\
\hline & Stunted & $6.56 \pm 0.69 \mathrm{~A}$ & \\
\hline
\end{tabular}




\begin{tabular}{|c|c|c|c|}
\hline & Groups & Value & $P$ values \\
\hline & Wasted & $6.25 \pm 0.9 \mathrm{~A}$ & \\
\hline & Stunted and Wasted & $5.65 \pm 0.3 \mathrm{~A}$ & \\
\hline \multirow[t]{4}{*}{ Subscapular (mm) } & Normal & $8.39 \pm 0.21 \mathrm{~A}$ & \multirow[t]{4}{*}{$0 \star \star$} \\
\hline & Stunted & $8.3 \pm 0.72 \mathrm{~A}$ & \\
\hline & Wasted & $6.13 \pm 0.34 \mathrm{~B}$ & \\
\hline & Stunted and Wasted & $6.22 \pm 0.21 B$ & \\
\hline \multirow[t]{4}{*}{ Suprailiac (mm) } & Normal & $43.63 \pm 1.08 \mathrm{~A}$ & \multirow[t]{4}{*}{$0.133^{\mathrm{NS}}$} \\
\hline & Stunted & $41.57 \pm 0.59 B$ & \\
\hline & Wasted & $39.84 \pm 0.76 \mathrm{BC}$ & \\
\hline & Stunted and Wasted & $39.16 \pm 0.38 \mathrm{C}$ & \\
\hline
\end{tabular}


Table 4

Anthropometric of children

\begin{tabular}{|c|c|c|c|}
\hline & Groups & Value & $P$ values \\
\hline \multirow[t]{4}{*}{ Waist Circumference (cm) } & Normal & $43.18 \pm 0.49 \mathrm{~A}$ & \multirow[t]{4}{*}{$0.708^{N S}$} \\
\hline & Stunted & $42.25 \pm 1.19 \mathrm{AB}$ & \\
\hline & Wasted & $39.5 \pm 0.72 \mathrm{BC}$ & \\
\hline & Stunted and Wasted & $39.26 \pm 0.46 C$ & \\
\hline \multirow[t]{4}{*}{$\operatorname{MUAC}(\mathrm{cm})$} & Normal & $13.91 \pm 0.3 \mathrm{~A}$ & \multirow[t]{4}{*}{$0 * *$} \\
\hline & Stunted & $13.74 \pm 0.1 \mathrm{~A}$ & \\
\hline & Wasted & $11.69 \pm 0.19 B$ & \\
\hline & Stunted and Wasted & $11.45 \pm 0.12 \mathrm{~B}$ & \\
\hline \multirow[t]{4}{*}{ Head Circumference $(\mathrm{cm})$} & Normal & $44.5 \pm 0.57 \mathrm{AB}$ & \multirow[t]{4}{*}{0 ** } \\
\hline & Stunted & $44.27 \pm 0.31 \mathrm{~A}$ & \\
\hline & Wasted & $42.87 \pm 0.4 \mathrm{BC}$ & \\
\hline & Stunted and Wasted & $42.14 \pm 0.28 \mathrm{C}$ & \\
\hline \multirow[t]{4}{*}{ Chest Circumference (cm) } & Normal & $43.63 \pm 1.08 \mathrm{~A}$ & \multirow[t]{4}{*}{0 ** } \\
\hline & Stunted & $41.57 \pm 0.59 \mathrm{~B}$ & \\
\hline & Wasted & $39.84 \pm 0.76 \mathrm{BC}$ & \\
\hline & Stunted and Wasted & $39.16 \pm 0.38 \mathrm{C}$ & \\
\hline \multirow[t]{4}{*}{ Neck Circumference (cm) } & Normal & $24.73 \pm 0.29 \mathrm{~A}$ & \multirow[t]{4}{*}{$0 \star \star$} \\
\hline & Stunted & $23.86 \pm 0.46 \mathrm{AB}$ & \\
\hline & Wasted & $23.17 \pm 0.18 \mathrm{~B}$ & \\
\hline & Stunted and Wasted & $21.4 \pm 0.27 \mathrm{C}$ & \\
\hline
\end{tabular}


Table 5

Anthropometric of mothers

\begin{tabular}{|c|c|c|c|}
\hline & Groups & Value & $P$ values \\
\hline \multirow[t]{4}{*}{ Pulse Rate } & Normal & $96 \pm 13.99 A$ & \multirow[t]{4}{*}{$0.321^{N S}$} \\
\hline & Stunted & $92.87 \pm 13.8 \mathrm{~A}$ & \\
\hline & Wasted & $90.26 \pm 15 \mathrm{~A}$ & \\
\hline & Stunted and Wasted & $88.68 \pm 13.41 \mathrm{~A}$ & \\
\hline \multirow[t]{4}{*}{ Temperature } & Normal & $98.4 \pm 0.77 \mathrm{~A}$ & \multirow[t]{4}{*}{$0.166^{N S}$} \\
\hline & Stunted & $98.3 \pm 0.66 \mathrm{~A}$ & \\
\hline & Wasted & $98.19 \pm 0.33 \mathrm{~A}$ & \\
\hline & Stunted and Wasted & $98.06 \pm 0.18 \mathrm{~A}$ & \\
\hline \multirow[t]{4}{*}{ Blood Oxygen Saturation } & Normal & $97.79 \pm 1.46 \mathrm{~A}$ & \multirow[t]{4}{*}{$0.465^{N S}$} \\
\hline & Stunted & $97.53 \pm 1.3 \mathrm{~A}$ & \\
\hline & Wasted & $97.4 \pm 1.4 \mathrm{~A}$ & \\
\hline & Stunted and Wasted & $97.13 \pm 1.36 \mathrm{~A}$ & \\
\hline \multirow[t]{4}{*}{ Height (cm) } & Normal & $152.17 \pm 5.24 \mathrm{~A}$ & \multirow[t]{4}{*}{$0.692^{N S}$} \\
\hline & Stunted & $151.27 \pm 8.42 \mathrm{~A}$ & \\
\hline & Wasted & $151.15 \pm 6.05 \mathrm{~A}$ & \\
\hline & Stunted and Wasted & $150.25 \pm 6.16 \mathrm{~A}$ & \\
\hline \multirow[t]{4}{*}{ Weight (kg) } & Normal & $64.55 \pm 8.31 \mathrm{~A}$ & \multirow[t]{4}{*}{$0.395^{N S}$} \\
\hline & Stunted & $61.67 \pm 12.51 \mathrm{~A}$ & \\
\hline & Wasted & $60.46 \pm 11.48 \mathrm{~A}$ & \\
\hline & Stunted and Wasted & $57.72 \pm 13.04 \mathrm{~A}$ & \\
\hline \multirow[t]{4}{*}{ Body Fat (\%) } & Normal & $34.39 \pm 4.42 \mathrm{~A}$ & \multirow[t]{4}{*}{0.298} \\
\hline & Stunted & $34.74 \pm 4.96 \mathrm{~A}$ & \\
\hline & Wasted & $35.75 \pm 5.19 A$ & \\
\hline & Stunted and Wasted & $37.38 \pm 2.75 \mathrm{~A}$ & \\
\hline \multirow[t]{2}{*}{ Body Water (\%) } & Normal & $44.66 \pm 4.59 \mathrm{~A}$ & \multirow[t]{2}{*}{$0.627^{\mathrm{NS}}$} \\
\hline & Stunted & $43.74 \pm 4.76 \mathrm{~A}$ & \\
\hline
\end{tabular}




\begin{tabular}{|c|c|c|c|}
\hline & Groups & Value & $P$ values \\
\hline & Wasted & $43.65 \pm 4.64 \mathrm{~A}$ & \\
\hline & Stunted and Wasted & $42.54 \pm 3.05 \mathrm{~A}$ & \\
\hline \multirow[t]{4}{*}{ Muscle Mass (\%) } & Normal & $30.29 \pm 1.88 \mathrm{~A}$ & \multirow[t]{4}{*}{$0.815^{N S}$} \\
\hline & Stunted & $31.57 \pm 4.03 \mathrm{~A}$ & \\
\hline & Wasted & $31.58 \pm 2.84 \mathrm{~A}$ & \\
\hline & Stunted and Wasted & $31.49 \pm 3.65 \mathrm{~A}$ & \\
\hline \multirow[t]{4}{*}{ Bone Mass (\%) } & Normal & $9.44 \pm 0.41 \mathrm{~A}$ & \multirow[t]{4}{*}{$0.487^{N S}$} \\
\hline & Stunted & $9.33 \pm 0.49 \mathrm{~A}$ & \\
\hline & Wasted & $9.33 \pm 0.44 \mathrm{~A}$ & \\
\hline & Stunted and Wasted & $9.19 \pm 0.62 \mathrm{~A}$ & \\
\hline
\end{tabular}


Table 6

Anthropometric of mothers

\begin{tabular}{|c|c|c|c|}
\hline & Groups & Value & $P$ values \\
\hline \multirow[t]{4}{*}{ AMR } & Normal & $1676.75 \pm 150.9 A$ & \multirow[t]{4}{*}{0.379 NS } \\
\hline & Stunted & $1650.94 \pm 190.3 \mathrm{~A}$ & \\
\hline & Wasted & $1627.01 \pm 188.2 \mathrm{~A}$ & \\
\hline & Stunted and Wasted & $1579.93 \pm 208.1 \mathrm{~A}$ & \\
\hline \multirow[t]{4}{*}{ BMR } & Normal & $1368.23 \pm 1059 A$ & \multirow[t]{4}{*}{$0.824^{N S}$} \\
\hline & Stunted & $1317.75 \pm 99.1 \mathrm{~A}$ & \\
\hline & Wasted & $1267.62 \pm 139.7 \mathrm{~A}$ & \\
\hline & Stunted and Wasted & $1238.23 \pm 163.5 \mathrm{~A}$ & \\
\hline \multirow[t]{4}{*}{ Waist Circumference (cm) } & Normal & $95.63 \pm 6.16 \mathrm{~A}$ & \multirow[t]{4}{*}{$0.786^{N S}$} \\
\hline & Stunted & $91.87 \pm 9.87 \mathrm{~A}$ & \\
\hline & Wasted & $91.63 \pm 12.87 \mathrm{~A}$ & \\
\hline & Stunted and Wasted & $92.55 \pm 10.09 \mathrm{~A}$ & \\
\hline \multirow[t]{4}{*}{ MUAC (cm) } & Normal & $27.35 \pm 2.39 \mathrm{~A}$ & \multirow[t]{4}{*}{$0.433^{N S}$} \\
\hline & Stunted & $26.08 \pm 3.11 \mathrm{~A}$ & \\
\hline & Wasted & $25.88 \pm 3.04 \mathrm{~A}$ & \\
\hline & Stunted and Wasted & $25.36 \pm 3.58 \mathrm{~A}$ & \\
\hline \multirow[t]{4}{*}{ Head Circumference (cm) } & Normal & $53.07 \pm 1.85 \mathrm{~A}$ & \multirow[t]{4}{*}{$0.867^{N S}$} \\
\hline & Stunted & $52.92 \pm 2.09 \mathrm{~A}$ & \\
\hline & Wasted & $52.92 \pm 1.7 \mathrm{~A}$ & \\
\hline & Stunted and Wasted & $52.5 \pm 1.58 \mathrm{~A}$ & \\
\hline \multirow[t]{4}{*}{ Chest Circumference (cm) } & Normal & $89.88 \pm 7.38 \mathrm{~A}$ & \multirow[t]{4}{*}{$0.806^{\mathrm{NS}}$} \\
\hline & Stunted & $87.65 \pm 11.63 \mathrm{~A}$ & \\
\hline & Wasted & $86.65 \pm 9.67 \mathrm{~A}$ & \\
\hline & Stunted and Wasted & $86.4 \pm 11.35 \mathrm{~A}$ & \\
\hline \multirow[t]{2}{*}{ Neck Circumference (cm) } & Normal & $32.89 \pm 4.96 \mathrm{~A}$ & \multirow[t]{2}{*}{$0.261^{\mathrm{NS}}$} \\
\hline & Stunted & $32.68 \pm 1.98 \mathrm{~A}$ & \\
\hline
\end{tabular}




\begin{tabular}{|lll|}
\hline Groups & Value & P values \\
\hline Wasted & $32.16 \pm 2.56 \mathrm{~A}$ \\
\hline Stunted and Wasted & $31.55 \pm 2.76 \mathrm{~A}$ \\
\hline
\end{tabular}

Table 7

FFQ of children

\begin{tabular}{|lll|}
\hline Food group & Children (6-24) & Children (24-60) \\
\hline Cereals & $2.1 \pm 2.65 \mathrm{~B}$ & $10.41 \pm 6.45 \mathrm{~A}$ \\
\hline Fruits & $2.74 \pm 3.78 \mathrm{~B}$ & $7.87 \pm 14.47 \mathrm{~A}$ \\
\hline Vegetable & $0.47 \pm 0.85 \mathrm{~B}$ & $1.18 \pm 1.53 \mathrm{~A}$ \\
\hline Meat & $0.66 \pm 1.49 \mathrm{~B}$ & $2.87 \pm 2.78 \mathrm{~A}$ \\
\hline Milk & $68.86 \pm 35.26 \mathrm{~A}$ & $53.61 \pm 53.1 \mathrm{~A}$ \\
\hline Fat \& oil & $0.34 \pm 1.37 \mathrm{~B}$ & $3.13 \pm 4.02 \mathrm{~A}$ \\
\hline Junk/Snack & $4.78 \pm 6.3 \mathrm{~B}$ & $8.6 \pm 7.42 \mathrm{~A}$ \\
\hline Miscellaneous & $0.86 \pm 2.29 \mathrm{~B}$ & $6.73 \pm 6.99 \mathrm{~A}$ \\
\hline Water (L) & $0.73 \pm 0.69 \mathrm{~B}$ & $1.75 \pm 0.71 \mathrm{~A}$ \\
\hline
\end{tabular}


Table 8

FFQ of mothers

\begin{tabular}{|c|c|c|c|}
\hline Food group & Groups & Value & $P$ values \\
\hline \multirow[t]{4}{*}{ Cereals } & Normal & $72.5 \pm 2.44 \mathrm{~A}$ & \multirow[t]{4}{*}{$0.494^{\mathrm{NS}}$} \\
\hline & Stunted & $71 \pm 2.2 \mathrm{~A}$ & \\
\hline & Wasted & $64.27 \pm 1.12 \mathrm{~A}$ & \\
\hline & Stunted and Wasted & $63.13 \pm 2.21 \mathrm{~A}$ & \\
\hline \multirow[t]{4}{*}{ Fruits } & Normal & $16.81 \pm 1.69 \mathrm{~A}$ & \multirow[t]{4}{*}{$0.483^{\mathrm{NS}}$} \\
\hline & Stunted & $13.23 \pm 1.71 \mathrm{~A}$ & \\
\hline & Wasted & $12.37 \pm 1.38 \mathrm{~A}$ & \\
\hline & Stunted and Wasted & $9.5 \pm 1.54 \mathrm{~A}$ & \\
\hline \multirow[t]{4}{*}{ Vegetable } & Normal & $24.67 \pm 1.01 \mathrm{~A}$ & \multirow[t]{4}{*}{$0.262^{\mathrm{NS}}$} \\
\hline & Stunted & $20.26 \pm 1.09 \mathrm{AB}$ & \\
\hline & Wasted & $18.56 \pm 1.98 \mathrm{AB}$ & \\
\hline & Stunted and Wasted & $15.25 \pm 1.76 \mathrm{~B}$ & \\
\hline \multirow[t]{4}{*}{ Meat } & Normal & $7.5 \pm 1.43 \mathrm{~A}$ & \multirow[t]{4}{*}{$0.823^{N S}$} \\
\hline & Stunted & $6.42 \pm 1.09 \mathrm{~A}$ & \\
\hline & Wasted & $6.23 \pm 1.05 \mathrm{~A}$ & \\
\hline & Stunted and Wasted & $5.73 \pm 1.19 \mathrm{~A}$ & \\
\hline \multirow[t]{4}{*}{ Milk } & Normal & $12.77 \pm 1.58 \mathrm{~A}$ & \multirow[t]{4}{*}{$0.995^{\mathrm{NS}}$} \\
\hline & Stunted & $10.69 \pm 1.58 \mathrm{AB}$ & \\
\hline & Wasted & $9.13 \pm 1.2 \mathrm{AB}$ & \\
\hline & Stunted and Wasted & $7.88 \pm 1.49 \mathrm{~B}$ & \\
\hline \multirow[t]{4}{*}{ Fat and oil } & Normal & $12.75 \pm 1.89 \mathrm{~B}$ & \multirow[t]{4}{*}{$0.208^{N S}$} \\
\hline & Stunted & $17.27 \pm 1.62 \mathrm{AB}$ & \\
\hline & Wasted & $17.69 \pm 1.31 \mathrm{AB}$ & \\
\hline & Stunted and Wasted & $18.17 \pm 1.19 \mathrm{~A}$ & \\
\hline \multirow[t]{3}{*}{ Junk/ snack } & Normal & $13.5 \pm 1.43 \mathrm{AB}$ & \multirow[t]{3}{*}{$0.093^{\mathrm{NS}}$} \\
\hline & Stunted & $18.71 \pm 1.28 \mathrm{~B}$ & \\
\hline & Wasted & $23.4 \pm 1.89 \mathrm{AB}$ & \\
\hline
\end{tabular}




\begin{tabular}{|c|c|c|c|}
\hline Food group & Groups & Value & $P$ values \\
\hline & Stunted and Wasted & $26.98 \pm 1.8 \mathrm{~A}$ & \\
\hline \multirow[t]{4}{*}{ Miscellaneous food } & Normal & $0.48 \pm 0.01 \mathrm{~A}$ & \multirow[t]{4}{*}{$0.372^{\mathrm{NS}}$} \\
\hline & Stunted & $0.6 \pm 0.29 A$ & \\
\hline & Wasted & $0.87 \pm 0.17 \mathrm{~A}$ & \\
\hline & Stunted and Wasted & $1.75 \pm 0.26 \mathrm{~A}$ & \\
\hline \multirow[t]{4}{*}{ Water } & Normal & $12.67 \pm 1.24 \mathrm{~A}$ & \multirow[t]{4}{*}{$0.325^{\mathrm{NS}}$} \\
\hline & Stunted & $9.91 \pm 1.03 \mathrm{AB}$ & \\
\hline & Wasted & $9.39 \pm 1.25 \mathrm{AB}$ & \\
\hline & Stunted and Wasted & $7.19 \pm 1.37 \mathrm{~B}$ & \\
\hline
\end{tabular}

